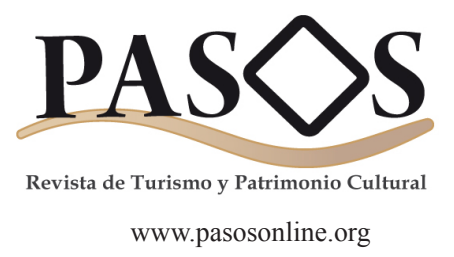

https://doi.org/10.25145/j.pasos.2012.10.026

Vol. $10 \mathrm{~N}^{\circ}$ 2. Special Issue. Pp. 47-58. 2012

\title{
Travel motivations, behavior and requirements of European senior tourists to Thailand
}

\author{
Ranee Esichaikul ${ }^{\mathrm{i}}$ \\ Sukhothai Thammathirat Open University (Thailand)
}

\begin{abstract}
The purposes of this research were to examine the travel motivations and travel behavior of European senior tourists in Thailand, and to analyze the importance and satisfaction of their travel requirements regarding accommodation, accessibility, attractions, amenities and public services. Questionnaires were used to collect data from 430 European senior tourists aged over 55 years traveling in Thailand. Thirty-seven in-depth interviews were also conducted to gain the perspectives of many stakeholders from both public and private sectors. Besides quantitative and qualitative analysis, Importance-Performance Analysis was conducted. Research findings showed that the principal travel motivations of sampled senior European tourists were rest and relaxation. The majority of respondents had traveled to Thailand for the first time and intended to stay in Thailand for 15 days or more for leisure and sightseeing activities. Three major requirements of European senior tourists were safety of the destination, location of accommodation, and presence of natural attractions. The result of this research suggests potential policies and measures for public and private sector development.
\end{abstract}

Keywords: Senior European tourist; Travel behavior; Motivation and requirements; Thailand.

Título: Motivaciones, comportamiento y requerimientos de turistas senior europeos de viaje por Tailandia

Resumen: Los objetivos de esta investigación fueron examinar las motivaciones y el comportamiento de los turistas senior europeos de viaje por Tailandia y analizar la importancia y satisfacción de sus necesi-dades de viaje con respecto al alojamiento, accesibilidad, atracciones e instalaciones y servicios públi-cos. Se utilizaron cuestionarios para recopilar datos de 430 turistas Europeos senior de más de 55 años que viajaban por Tailandia. También se llevaron a cabo treinta y siete entrevistas en profundidad para obtener la perspectiva de las partes interesadas del sector público y privado. Además del análisis cuanti-tativo y cualitativo se llevó a cabo un análisis de importancia-rendimiento. Los resultados de la investi-gación demuestran que las motivaciones principales de viaje de los turistas europeos senior incluyen descanso y relajación. La mayoría de los encuestados viajaba a Tailandia por primera vez con la inten-ción de permanecer en el país durante 15 días o más, por ocio y turismo. Tres requisitos principales de los turistas europeos senior son la seguridad del destino, el lugar de alojamiento y la presencia de atrac-tivos naturales. El resultado de esta investigación sugiere posibles medidas políticas para el desarrollo público y privado del sector.

Palabras clave: Turista senior europeo; Comportamiento de viaje; Motivación y necesidades; Tailandia.

i School of Management Science, Sukhothai Thammathirat Open University, Thailand, ranee.esi@stou.ac.th 


\section{Introduction}

Dramatic improvements in health care and life expectancy have produced rapid growth in the world's senior population. At the end of the twentieth century, 11 percent of the world's population was aged 60 or above, and it is estimated that 20 percent will be 60 years or older by 2050 (United Nations Population Division, 1998, cited in Hall, $2006: 12-13)$. In fewer than 20 years, fully one third of the population of Japan and Germany will be 60 or older. More than a quarter of the population of France, the United Kingdom and the Republic of Korea will fall into the same pattern (Dann, 2001; World Tourism Organization, 2005:13).

The aging population in many industrialized countries draws attention from the tourism industry mainly because of its substantial size, increasing purchasing power and more time available for travel after retirement. Seniors often have higher levels of discretionary income due to accumulation of lifetime income and pensions (You and O'Leary, 1999; Bai et al., 2001) The longer lifespan and greater numbers of seniors who are educated, healthy and self-sufficient members of society, together with larger discretionary income, may encourage them to participate in society and leisure activities such as overseas travel (Sellick and Muller, 2004). Furthermore, time flexibility after retirement makes the senior market more attractive to tourism businesses that suffer from seasonal demand fluctuations (Jang and $\mathrm{Wu}, 2006)$. The senior market has been thus cited as one of the most important consumer segments of the tourism industry. (Shoemaker, 2000; Bai et al., 2001; Horneman et al., 2002; Jang and Wu, 2006).

Thailand is one of the most popular tourist destinations in Southeast Asia because of its diverse nature, rich culture and friendly people. Thailand's tourism experienced continued growth except for a small decline in 2009 due to various internal and external disruptive factors. In 2007, international tourism arrivals reached 14.4 million, representing a growth of $2 \%$, and international tourism receipts reached US\$ 15.5 million (Ministry of Tourism and Sports, 2008). The tourism industry represented 14.1 percent of the GDP and created over 3.9 mil- $^{-}$ lion jobs, representing $10.6 \%$ of total employment in 2008 (World Economic Forum, 2009). The Tourism Authority of Thailand (TAT) has recognized the international senior travel market as a potential growth segment; nevertheless, the number of inbound senior tourists has not expanded rapidly
(TAT, 2006). In 2007, international tourism arrivals aged 55 or above increased from 2,119,675 in 2006 to $2,259,161$ in 2007 , representing $15.3 \%$ and $15.6 \%$ of total international tourists, respectively (Immigration Bureau, 2008). European tourists represent the second largest group of inbound tourists, after East Asian tourists. However, their average length of stay in Thailand is the longest-15.26 days in 2007-and almost three times longer than those of East Asian tourists, which has a significant effect on tourist expenditure

\section{Objectives of the study}

Understanding seniors' travel motivations and behavior is fundamental to travel businesses that compete for this potential growth market (Crompton, 1979; Jang and Wu, 2006). Numerous research projects on travel motivation and behavior have been conducted in order to understand and to better satisfy the needs of senior tourists (Backman et al., 1999, Cleaver et al., 1999; Sellick and Muller, 2004; Huang and Tsai, 2003; Jang and Wu, 2006; Hsu et al., 2008. The travel motivation of Japanese senior travelers to Thailand has been examined recently (Sangpikul, 2008); nevertheless, little attention has been devoted to understanding the European senior tourist market in Thailand. Therefore, this study examines the travel motivations and travel behavior of European senior tourists in Thailand, and analyzes the importance and satisfaction of travel requirements of European senior tourists in five tourism components in Thailand, including accommodation, accessibility, attractions, amenities and public services. Understanding the travel requirements of senior tourists will be useful for travel planners and marketers to design specific market strategies and to adapt tourist products to the potential needs of senior tourists.

\section{Literature review}

\section{Seniors' travel motivations}

Motivation is a state of need or a condition that drives an individual toward certain types of action that are seen as likely to bring satisfaction (Moutinho, 2000). Motivation has also been defined as a force within an individual that causes him or her to do something to fulfill a biological need or psychological desire (Fridgen, 1996). Travel motivation relates to why people travel (Hsu and Huang, 
2008). Motivations for travel cover a broad range of human behaviors and human experiences. A list of travel motivations might include: relaxation, excitement, social interactions with friends, adventure, family interactions, status, physical challenges, and escape from routine or stress. Pearce (1982) applied Maslow's hierarchy to tourist motivation and behavior, and argued that tourists were attracted to destinations because of the possibility of fulfilling self-actualization, love and belongingness, and physiological needs.

There are several related studies that help understanding of seniors' travel motivations. Cleaver et al. (1999) stated that the senior market is not homogeneous and identified seven senior tourist segments, which they labeled according to motivation: Nostalgics, Friendlies, Learners, Escapists, Thinkers, Status-Seekers, and Physicals. Backman et al. (1999) identified differences and similarities between younger ( 55 to 64 ) and older seniors (65 or older). Their study revealed that younger senior travelers were more interested in relaxation and leisure activities while older seniors were interested in educational or natural attractions. Fleischer and Pizam (2002) reviewed previous studies and reported that seniors' most common travel motivations were rest and relaxation, social interaction, physical exercise, learning, nostalgia, and excitement. Likewise, Horneman et al. (2002) found that seniors' motivations were shifting toward more active pursuits with a strong focus on health and fitness and concluded that the most frequently identified motivations for Australian seniors were education/ learning, rest/relaxation, physical exercise/fitness and visiting friends and relatives. More recently, Huang and Tsai (2003) reviewed previous studies and indicated that travel motivation can be classified into rest and relaxation, social interaction, health, learning, exploration, escape, value for money, nostalgia and the opportunity to visit historical sites. In addition, Jang and Wu (2006) examined the travel motivations of Taiwanese seniors and identified knowledge-seeking and cleanliness and safety as the most important push and pull motivations, respectively.

\section{Senior Tourist Profiles and Requirements}

An examination of previous literature took note of many studies on senior travelers' profiles, preferences, and requirements. To identify seniors' traveler profiles, Anderson and Langmeyer (1982) $\mathrm{ex}^{-}$ amined two senior groups and reported that both over-50 and under-50 groups are likely to take pleasure trips for rest and relaxation and for visiting family and relatives, but over-50 groups are more likely to visit historical sites. Javalgi et al. (1992) revealed that non-seniors are a better-educated group than seniors and are more likely to engage in a detailed information search process before making a purchase decision. Seniors are more likely to buy trip packages covering both transportation and accommodation. Zimmer et al. (1995) focused on characteristics of older adults who travel and claimed that age, education, and mobility problems were the most critical discriminating variables between travelers and non-travelers.

Some tourism researchers examined senior travelers' preferences. Koss (1994) stated that senior travelers want hotel packages and promotions that are exciting, creative, and value-oriented. Bai et al. (2001) investigated preferences among British, German and Japanese seniors and found that the number of people in travel parties and the length of the trip were significant when all three groups chose package tours. Hsu (2001) argued that the reputation of tour operators and seniors' health and safety concerns were most important. Baloglu and Shoemaker (2000) claimed that senior travelers' decisions to take motor coach tours could be predicted from their demographic, psychological, and psychographic characteristics. In addition, Lindqvist and Bjork (2000) noted that senior tourists showed that perceived safety was an important factor in their decision making whose perceived importance increases as the tourist grows older.

\section{Senior Tourist Behavioral Patterns}

Many studies have focused on examining senior traveler's behavior patterns. Shoemaker (1989) surveyed Pennsylvania seniors on travel behavior and reasons for travel and segmented the senior market into three sub-groups that he called 'family travelers', 'active resters' and the 'older set'. Romsa and Blenman (1989) noted vacation patterns of elderly Germans, examining modes of travel, destinations, length of vacation, accommodations, popularity activities and vacation memories. Huang and Tsai (2003) discovered that Taiwanese senior travelers do not want to join typical all-inclusive package tours. They want a more elegant, less regimented itinerary and demand quality tour content and services. Littrell (2004) examined tourism activities 
and shopping behaviors of senior travelers. In that study, travel activities included outdoors, cultural, and sports and entertainment tourism. Tourist profiles differed based on the likelihood of shopping at retail venues, preferred shopping mall characteristics and sources of shopping information.

Motivation is a state of need condition that drives an individual toward certain types of action that are seen as likely to bring satisfaction (Moutinho, 2000). Motivation is also defined as a force within an individual that causes him or her to do something to fulfill a biological need or psychological desire (Fridgen, 1996). Travel motivation relates to why people travel (Hsu and Huang, 2008). Motivations for travel cover a broad range of human behaviors and experiences. A list of these motivations might include: relaxation, excitement, social interactions with friends, adventure, family interactions, status, physical challenges, and escape from routine or stress. Pearce (1982) applied Maslow's hierarchy to tourist motivation and behavior, and argued that tourists were attracted to destinations because of the possibility of fulfilling self-actualization, love and belongingness, and physiological needs.

There are several related studies that help understanding of seniors' travel motivations. Cleaver et al. (1999) stated that the senior market is not homogeneous and identified seven senior tourist segments, which they labeled according to motivation: Nostalgics, Friendlies, Learners, Escapists, Thinkers, Status-Seekers, and Physicals. Backman et al. (1999) identified differences and similarities between younger (55 to 64) and older seniors (65 or older). Their study revealed that younger senior travelers were more interested in relaxation and leisure activities while older seniors were interested in educational or natural attractions. Fleischer and Pizam (2002) reviewed previous studies and reported that seniors' most common travel motivations were rest and relaxation, social interaction, physical exercise, learning, nostalgia, and excitement. Likewise, Horneman et al. (2002) found that seniors' motivations were shifting toward more active pursuits with a strong focus on health and fitness and concluded that the most frequently identified motivations for Australian seniors were education/ learning, rest/relaxation, physical exercise/fitness and visiting friends and relatives. More recently, Huang and Tsai (2003) reviewed previous studies and indicated that travel motivation can be classified into rest and relaxation, social interaction, health, learning, exploration, escape, value for mon- ey, nostalgia and the opportunity to visit historical sites. In addition, Jang and Wu (2006) examined the travel motivations of Taiwanese seniors and identified knowledge-seeking and cleanliness and safety as the most important push and pull motivations, respectively.

\section{Methodology}

This research was carried out through a threestage process. Firstly, an extensive review of literature focusing on senior tourist motivations, behavior and travel requirements was conducted to identify travel motivations and behavioral patterns performed by senior tourists. The motivations, travel behavior and requirements frequently cited in literature were selected to be included in questionnaire items.

In the second stage of the research, a questionnaire was developed to collect quantitative data. The questionnaire instrument consisted of five parts. The first part dealt with personal characteristics of the respondents. The second part included questions of travel behavior and trip characteristics. The third part was designed to gather opinions on travel motivations. Senior tourists were asked to give opinions on a five-point Likert scale (1- strongly disagree to 5 - strongly agree). The fourth part included 17 attributes of travel requirements for which senior tourists were asked to rate the perceived importance of each of the attributes in considering their destination selection. These 17 attributes covered major tourism components of destination selection, including accommodation, accessibility, attractions amenities and public services. A five-point Likert scale was used to measure the importance variables (1 - very unimportant to 5 - very important). The final part covered 17 attributes of travel requirements for which senior tourists were asked to rate the satisfaction of performance of each of the attributes after travelling in Thailand. Content validity of these questionnaire items was evaluated by two tourism professionals and two faculty members from a tourism business school. Subsequently, a pilot test was conducted to assess how well the research instrument captured the constructs it was supposed to measure and to test the comprehension of the questionnaire items. Reliability of these questionnaire items was assessed by calculating Cronbach's alpha coefficients. The result of the reliability test was at 0.9354 , which meant that the questionnaire was reliable as an instrument for data collection. To 
increase a variety of international respondents, the questionnaire was translated into French as well.

The samples for this study were 400 senior tourists, aged 55 years and over who were travelling in Thailand. Using a convenience sampling method, data were collected through a self-administered questionnaire at major tourist destinations, including Bangkok, Chiangmai, Phuket, Pattaya and Hua-Hin in 2009. Out of 600 questionnaires distributed, 467 surveys were collected, of which 37 were discarded due to a large numbers of missing values. A total of 430 questionnaires were used for the data analysis. Statistical tools employed for descriptive analysis were frequency, percentage, mean, and standard deviation; and those for inferential statistical analysis were t-test, F-test, and least significant difference. Importance-Performance Analysis was also conducted.

Importance-Performance Analysis (IPA) is a practical technique used for understanding two dimensions of customer attributes: perceived importance and performance level. Since Martilla and James (1977) first introduced IPA to the marketing literature, it has been an effective tool used by researchers in various industries, including servicebased industries, such as tourism, spa, and hotel and food services (Farnum and Hall, 2007; Jang et al., 2009; Zhang and Chow, 2004; Koh et al., 2010).

Finally, an interview was developed as a method to collect qualitative data from major stakeholders, both public and private. These in-depth interviews focused on vital contexts of the European senior tourist market, and provided an assessment of strengths and weaknesses of managing tourism resources, facilities and services for the European senior market. Using a purposive sampling method, the key informants were contacted by phone for a brief interview to explain the purpose of the study. The research interview questions were then sent through e-mail or by post. After each interview, a record was transcribed, responses were coded and tentative categories were generated (Patton, 1990). A total of thirty-seven in-depth interviews were conducted, including 8 key informants from public sectors, such as policy planners from the Ministry of Tourism and Sports and the Tourism Authority of Thailand. Twenty-nine key informants were from various tourist-related businesses, such as tour operators, hotels, hospitals, spa operators and tourism trade associations. The length of these interviews varied from 35 minutes to 1 hour with an average of 51.48 minutes per interview.

\section{Results}

Table 1 shows the demographic characteristics of the respondents.

\begin{tabular}{|c|c|c|}
\hline Demographic characteristics & $\begin{array}{l}\text { Number of } \\
\text { respondents }\end{array}$ & Percentage \\
\hline \multicolumn{3}{|l|}{ Gender } \\
\hline Male & 280 & 65.12 \\
\hline Female & 150 & 34.88 \\
\hline \multicolumn{3}{|l|}{ Age } \\
\hline $55-59$ & 198 & 46.05 \\
\hline $60-64$ & 121 & 28.14 \\
\hline 65 and older & 111 & 25.81 \\
\hline \multicolumn{3}{|l|}{ Education } \\
\hline Elementary & 38 & 8.83 \\
\hline High school & 113 & 26.28 \\
\hline Technical/vocational & 73 & 16.98 \\
\hline College/university degree & 143 & 33.26 \\
\hline Graduate degree & 63 & 14.65 \\
\hline \multicolumn{3}{|l|}{ Marital status } \\
\hline Single & 77 & 17.91 \\
\hline Married & 291 & 67.67 \\
\hline Widowed & 24 & 5.58 \\
\hline Divorced & 38 & 8.84 \\
\hline \multicolumn{3}{|l|}{ Health status } \\
\hline Excellent & 173 & 40.23 \\
\hline Good & 221 & 51.40 \\
\hline Fair & 28 & 6.51 \\
\hline Poor & 8 & 1.86 \\
\hline \multicolumn{3}{|l|}{ Employment } \\
\hline Work full-time & 173 & 40.23 \\
\hline Work part-time & 64 & 14.89 \\
\hline Retired more than one year & 134 & 31.16 \\
\hline Retired 1 year or less & 43 & 10.00 \\
\hline Unemployed & 16 & 3.72 \\
\hline \multicolumn{3}{|l|}{ Economic status } \\
\hline Very abundant & 43 & 10.00 \\
\hline Abundant & 168 & 39.07 \\
\hline Enough & 206 & 47.91 \\
\hline A little difficult & 13 & 3.02 \\
\hline \multicolumn{3}{|l|}{ Income source } \\
\hline Pension & 142 & 33.02 \\
\hline Work/own savings & 270 & 62.79 \\
\hline Children's support & 4 & 0.93 \\
\hline Relatives or friend's support & 8 & 1.86 \\
\hline Social benefits & 6 & 1.40 \\
\hline \multicolumn{3}{|l|}{ Hobbies and interests } \\
\hline Reading & 273 & 63.49 \\
\hline Watching TV & 181 & 42.09 \\
\hline Planting & 96 & 22.33 \\
\hline Listening to music & 166 & 38.60 \\
\hline Travel & 325 & 75.58 \\
\hline Sporting & 178 & 41.40 \\
\hline Watching movie & 142 & 33.02 \\
\hline
\end{tabular}

Table 1.Demographic characteristics of the respondents $(\mathrm{N}=430)$

The table shows that $65.12 \%$ of the respondents were male. Nearly half of the respondents (46.05\%) were between age 55 and 59;28.14\% were between 60 and 64 and $25.81 \%$ were age 65 or older. $33.26 \%$ of the respondents had earned bachelor's degrees. 


\begin{tabular}{|l|c|c|}
\hline Travel motivations & Mean & Std. Dev. \\
\hline Rest and relaxation & 4.13 & 1.02 \\
\hline Visit to new places & 3.97 & 1.07 \\
\hline Learn and experience new things & 3.96 & 0.99 \\
\hline Get away from stress & 3.80 & 1.19 \\
\hline Escape from day-by-day activities & 3.69 & 1.18 \\
\hline Meet people and socialization & 3.64 & 1.02 \\
\hline Improve health and well-being & 3.60 & 1.00 \\
\hline Take challenge/experience an adventure & 3.59 & 1.05 \\
\hline Seek intellectual enrichment & 3.48 & 1.09 \\
\hline Exercise physically & 3.10 & 1.09 \\
\hline Visit family and friends & 2.98 & 1.44 \\
\hline
\end{tabular}

Table 2. Travel motivations $(N=430)$

\begin{tabular}{|l|c|c|}
\hline \multicolumn{1}{|c|}{ Attributes } & Mean & Std. Dev. \\
\hline Safety of the destination & 4.19 & 0.99 \\
\hline Location of accommodation & 4.02 & 1.06 \\
\hline Natural attractions & 4.01 & 0.94 \\
\hline Price of inclusive packages/hotels & 3.99 & 0.98 \\
\hline Variety of suitability of food and beverage & 3.97 & 0.91 \\
\hline Easy accessibility of destination & 3.94 & 0.95 \\
\hline Historical attractions & 3.84 & 0.96 \\
\hline Cultural attractions & 3.82 & 0.95 \\
\hline Local transportation & 3.80 & 0.93 \\
\hline Convenient immigration and customs procedure & 3.73 & 1.05 \\
\hline Availability of medical facilities & 3.73 & 1.04 \\
\hline Infrastructure & 3.71 & 0.98 \\
\hline Service quality of travel agents & 3.70 & 1.13 \\
\hline Service quality of tour leaders and tour guide & 3.64 & 1.13 \\
\hline Hotel accessibility and disability features & 3.41 & 1.18 \\
\hline Special events and festivals & 3.40 & 0.99 \\
\hline Leisure activities & 3.15 & 1.13 \\
\hline
\end{tabular}

Table 3. Importance of tourism attributes of travel requirements $(N=430)$

Over two-thirds of the respondents $(67.67 \%)$ were married. $40.23 \%$ worked part-time and $62.79 \%$ had their own savings as their income source. Half of the respondents identified self-perceived health status as 'good' (51.40\%) and self-perceived economic status as 'enough' (47.91\%). 27.67\% were British while $17.21 \%$ were Dutch and $13.72 \%$ were German; the remaining $41.4 \%$ were nationals of assorted other European countries.

For travel motivations, research findings in Table 2 showed that the three principal travel motivations of sampled European senior tourists were rest and relaxation $($ mean $=4.13)$, visits to new places $(3.97)$ and learning and experiencing new things (3.96).

As for travel behavior, the result showed that the majority of respondents $(41.40 \%)$ traveled to Thai- land for the first time, whereas $31.86 \%$ had visited Thailand more than 4 times. More than half of the respondents $(58.37 \%)$ planned to stay in Thailand for 15 days or more. Most of them traveled with their spouse (54.42\%), and arranged their trip by themselves (45.34\%). They visited Bangkok (59.77\%), Chiang Mai (40.93\%) and Phuket (34.88\%). The major reason to visit Thailand was friendly people (72.79\%). The major intended activity was leisure and sightseeing (72.56\%). Half of the respondents preferred to stay in a 4-star hotel (47.67\%), and used a car to travel around Thailand (41.86\%). The major source of information was family and friends (46.74\%). Their estimated daily expenditure was below US $\$ 100(41.86 \%)$ and $23.25 \%$ estimated between US $\$ 100^{-120}$. The largest number of $\mathrm{re}^{-}$ 


\begin{tabular}{|l|c|c|}
\hline \multicolumn{1}{|c|}{ Attributes } & Mean & Std. Dev. \\
\hline Safety of the destination & 4.10 & 0.95 \\
\hline Location of accommodation & 4.09 & 0.86 \\
\hline Natural attractions & 4.05 & 0.81 \\
\hline Price of inclusive packages/hotels & 4.03 & 0.94 \\
\hline Variety of suitability of food and beverage & 4.01 & 0.86 \\
\hline Easy accessibility of destination & 3.98 & 0.88 \\
\hline Historical attractions & 3.98 & 0.89 \\
\hline Cultural attractions & 3.96 & 0.88 \\
\hline Local transportation & 3.90 & 0.93 \\
\hline Convenient immigration and customs procedure & 3.82 & 0.97 \\
\hline Availability of medical facilities & 3.81 & 0.95 \\
\hline Infrastructure & 3.81 & 0.91 \\
\hline Service quality of travel agents & 3.79 & 1.03 \\
\hline Service quality of tour leaders and tour guide & 3.77 & 1.05 \\
\hline Hotel accessibility and disability features & 3.69 & 0.97 \\
\hline Special events and festivals & 3.68 & 0.94 \\
\hline Leisure activities & 3.52 & 0.94 \\
\hline
\end{tabular}

Table 4. Satisfaction of tourism attributes of travel requirements $(N=430)$

spondents preferred to visit Thailand in January (33.49\%). Almost all of the respondents (88.60\%) will revisit Thailand while $52.32 \%$ will revisit in the same year. Besides Thailand, 39.53\% of the respondents would most like to visit Vietnam.

A total of 430 respondents were surveyed and asked to rate the perceived importance of each of the 17 attributes of travel requirements in considering their destination selection. Table 3 shows that among respondents' travel requirements, safety of the destination was indicated as the most important $($ mean $=4.19)$, followed by 'location of accommodation' (4.02), and 'natural attractions' (4.01).

Likewise, Table 4 shows that the three top satisfactions of their travel requirements were safety of the destination (4.10), location of accommodation (4.09), and natural attractions (4.05). Moreover, Ftest and t-test indicated that differences in gender, age, education, employment, and health status of the respondents were significant factors in determining travel requirements.

In this study, IPA (Martilla and James, 1977 ) is used to analyze importance and satisfaction level of five tourism components of Thailand (17 attributes). In applying IPA to the current study, mean tourist ratings of importance and performance across 17 attributes are plotted against each other, and the resulting importance-performance (IP) space is divided into four quadrants. Figure 1 shows the results of IPA. Quadrant 1 top left (Concentration Here) represents highly important factors with low levels of service satisfaction. No factor that requires such high-priority improvements has been found. Quadrant 2 top right (Keep up the Good Work) represents important factors with a high level of satisfaction. Nine factors were found, including the location of the accommodation, the price of inclusive packages or hotels, the variety and suitability of food and beverages, easy accessibility to destinations, local transportation, natural attractions, historical attractions, cultural attractions, and safety of the destination. Thailand must thus maintain high service quality of these attributes in order to guarantee continued satisfaction. Quadrant 3 bottom left (Low Priority) represents factors that registered low levels of importance and low levels of satisfaction. Eight factors were found, including hotel accessibility and disability features, convenient immigration formalities and customs, special events and festivals, the service quality of travel agents, leisure activities, availability of medical facilities, and infrastructure. Although these factors ranked as low priority, some factors were close to the average mean. Thailand should consider giving priority to some of these areas. Finally, quadrant 4 bottom right (Possible Overkill) represents factors with low importance but high levels of satisfaction. The result showed no factors in this quadrant.

Furthermore, the in-depth interviews were conducted to investigate vital contexts of senior tourist market, and an assessment of strengths and weaknesses of tourism resources, facilities and services 
for European senior market. Various key informants identified some fundamental contexts of European senior market in Thailand as shown in Table 5. Results from qualitative data pointed out significant strengths and weaknesses of managing tourism resources, facilities and services for European senior tourists in Thailand as shown in Table 6.

Subsequently, results from interviews revealed that senior European tourists can be classified into three groups. The first group consists of senior tourists between ages 55 and 65 who are still working and often visit Thailand for leisure purposes for two weeks in winter. Members of this group may also buy package tours and visit Thailand for the first time. The second group is made up of retired senior tourists age 65 and older that usually travel to Thailand and stay for one to two months. They prefer to stay in 3 to 4 star hotels-often the same hotels every time. The hotel should be in town where supermarkets, restaurants, hospitals are in proximity. Lastly, long-stay senior tourists usually stay for $2-$ 3 months in self-catering accommodations.

Some travel to Thailand for medical treatment. Most senior European tourists travel to Thailand because of the friendly people, sun-sea-sand attrac- tions, local culture, warm climate, good food, value for money and high standard of medical care. The major problem of servicing senior tourists identified by key informants were communication (language) problems, lack of facilities for the disabled in public areas, lack of foreign language road signs, expensive local transport, short-term visa issues, and safety standards for transportation.

\section{Discussion and recommendations}

Comparative studies relating to travel motivations and behavior of senior tourists have been undertaken mostly in America and Europe. Some studies focused on Taiwanese senior travelers. Very little attention has been devoted to understanding the European senior tourists in Thailand. During the last decade, the number of European senior tourists in Thailand has not been increased significantly even though Tourism Authority of Thailand has recognized and attempted to promote this growing market. The travel behavior results revealed that $41.4 \%$ of respondents visited Thailand for the first time while $31.86 \%$ who were from affluent western countries, have visited Thailand more than

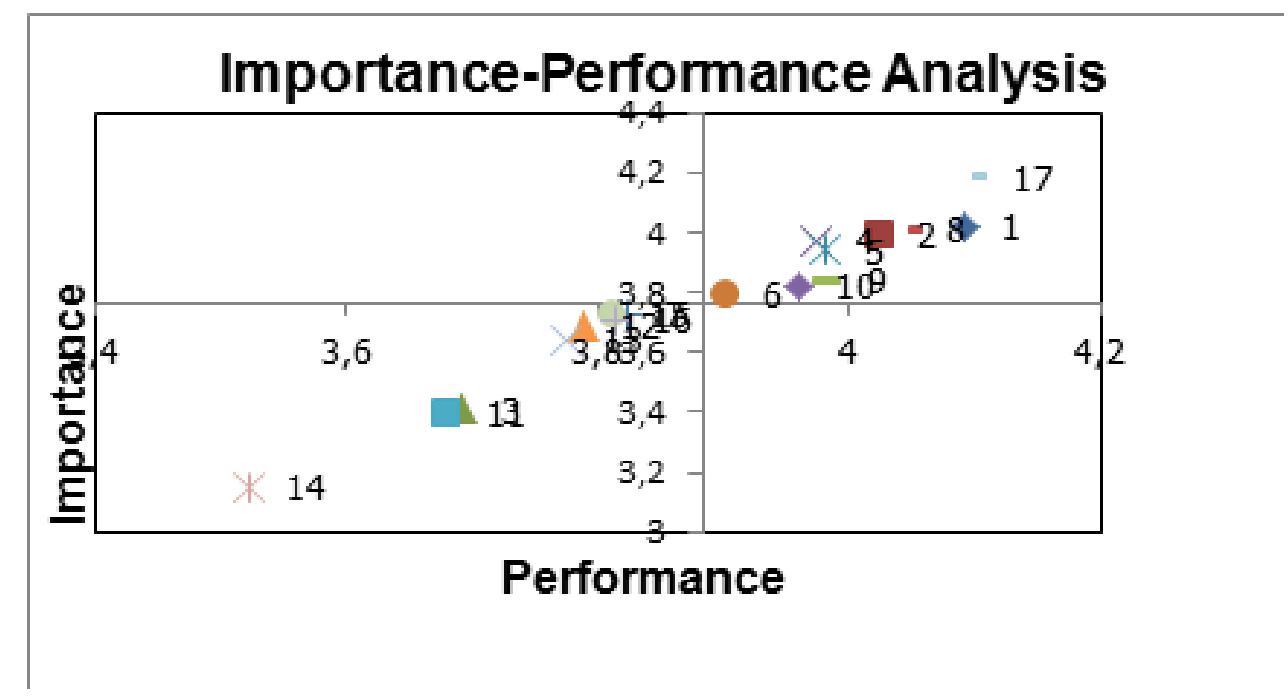

Figure 1.Importance Performance Analysis

Notes: 1 = location of accommodation; 2 = price of inclusive packages/hotels; $3=$ hotel accessibility; $4=$ variety and suitability of food and beverage; $5=$ easy accessibility to destination; $6=$ local transportation; $7=$ convenient immigration and customs procedure; 8 = natural attractions; $9=$ historical attractions; $10=$ cultural attractions; $11=$ special events and festivals; $12=$ service quality of travel agent; $13=$ service quality of tour leader and tour guide; 14 = leisure activities; 15 = availability of medical facilities; 16 = infrastructure; 17 = safety of destination. 


\begin{tabular}{|c|c|}
\hline Key informants & Contexts of European senior market \\
\hline Tour operators & $\begin{array}{l}\text { Most European senior tourists visiting Thailand are in middle level of income but like to } \\
\text { go abroad once to twice a year for leisure purposes and escape from cold winter for } \\
\text { sun-sea-sand. They can be classified into } 3 \text { groups: } \\
\text { (1) Age between } 55-65 \text { who are still employed but take vacation for } 2 \text { weeks in } \\
\text { Thailand during their winter. } \\
\text { (2) Age } 65 \text { and over that are retired and often travel to Thailand and stay for } 1-2 \\
\text { months. } \\
\text { (3) Long stay group who buy or rent a self-catering accommodation in Chiangmai or } \\
\text { Hua-Hin for } 2-3 \text { months. }\end{array}$ \\
\hline Hotels & $\begin{array}{l}\text { Most European senior tourists come to Thailand with their spouses. They like to rest } \\
\text { and relaxation and enjoy tranquility and being pampered by Thai people in a tropical } \\
\text { climate destination. They love the sea and wish to learn some local wisdom and } \\
\text { culture. }\end{array}$ \\
\hline TAT & $\begin{array}{l}\text { Senior tourists from Nordic and Baltic countries are more male }(55 \%) \text { between age } 55 \\
\text { and } 70 . \text { Most of them are married, healthy and working as middle level of employees or } \\
\text { businessmen. Their major source of income comes from business and social welfare. }\end{array}$ \\
\hline $\begin{array}{l}\text { Tourism } \\
\text { association }\end{array}$ & $\begin{array}{l}\text { Senior tourists who are in middle level of income would like to visit Thailand for leisure } \\
\text { and cultural activities. Some are employed while some have been retired. }\end{array}$ \\
\hline Hospitals & $\begin{array}{l}\text { Most of retired senior tourists like to visit Thailand. They are affluent and afford to pay } \\
\text { their medical expenses by themselves. They expect high level of medical services from } \\
\text { the hospitals. }\end{array}$ \\
\hline Spa c & $\begin{array}{l}\text { European senior tourists enjoy beauty of nature, outdoor weather and like to use spa } \\
\text { services. They often visit for spa treatment for a few hours. }\end{array}$ \\
\hline
\end{tabular}

Table 5. Vital contexts of European senior market in Thailand

4 times. This showed that more than one-third of the respondents were repeated visitors due to our friendly people and slightly higher number of respondents is first time visitors who perhaps have been recommended to visit Thailand by their family and/or friends. Besides Thailand, 39.53\% of the respondents would most like to visit Vietnam. More emerging destinations have developed and become very competitive to Thailand in the near future.

From the findings of this research, it is clear that travel motivations of the respondents are rest and relaxation (4.13), visits to new places (3.97) and learning and experiencing new things (3.96). Anderson and Langmeyer's (1982), Fleischer and Pizam's (2002), Horneman et al.'s (2002) studies of senior travel motivation are similar. Rest and relaxation is one of the fundamental human needs as mentioned by Pearce (1992). Patterson (2002) study result of searching for new things as senior travel motivation is in the same way. Senior travelers today are interested in discovering new things more than previous senior generation.

Safety of the destination is the most important factor for respondents which is similar to Hsu's (2001) and Lindqvist and Bjork's (2000) studies.
Many European cities maintain their high standard of safety and security, as a result senior tourists would expect the same level of safety while travelling. Perceived importance of safety tends to increase as tourists grow older. Moreover, natural attractions were found to be one of the most important factors for senior tourists, which is similar to Norman et al.'s (2001) study. A large number of senior tourists still enjoy sun-sea-sand vacation and is attracted to beauty of mountains and forests.

The results of this research provide some insight information of senior tourists for planners and marketers. In this case, it is necessary for Thailand to develop certain policy measures and strategies in public and private sectors. Important policies include tourism promotion for European senior tourists, for long stays and for medical tourists. Provision of safety protection for senior tourists, physical improvement of tourist destinations, development of easy and convenient accessibility, support for accommodation and attractions, and facility improvement for senior tourists should be taken into consideration if Thailand wants to attract more senior tourists from European countries. 


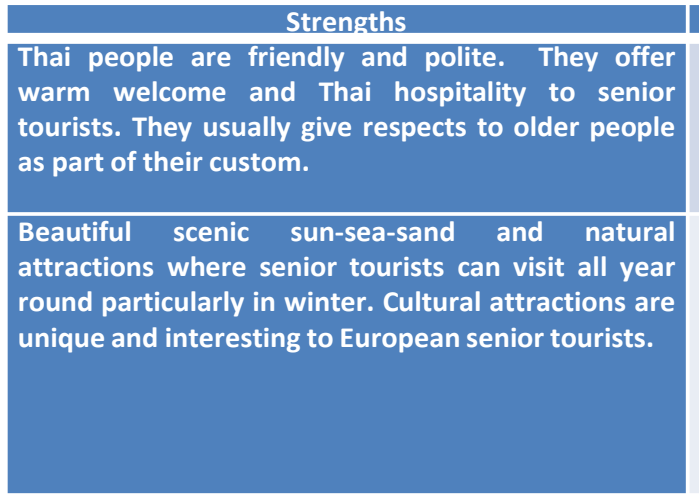

Trip to Thailand is inexpensive and value for money for European senior tourists.

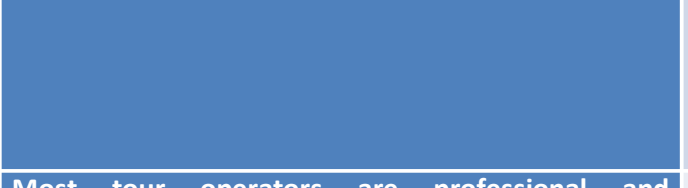

Most tour operators are professional and understand the nature and differences among European senior tourists. Tour operators are familiar with major tourist destinations. They can design tourism products according to customer needs. They provide standard and excellent services for tourists, such as quality tour guides, safe transfer/transport services.

Hotel staff usually provides friendly services and treat senior guests like their elder relatives. Senior tourists enjoy privacy, tranquility and safety in hotels or resorts by the sea or in the mountain areas.

Most hospital services are certified by $\mathrm{JCl}$, together with all modern medical equipments and facilities. Their warm, friendly trained medical assistants and staff provide quality services. Medical cost is reasonable to European standards.

Thai spa provides standard and quality services for authentic Thai ways, such as traditional Thai massage, Thai herbs, Thai healing, as well as Thai wisdom that has been well blended with the western style of well being. Spas are extremely affordable and popular among international tourists.

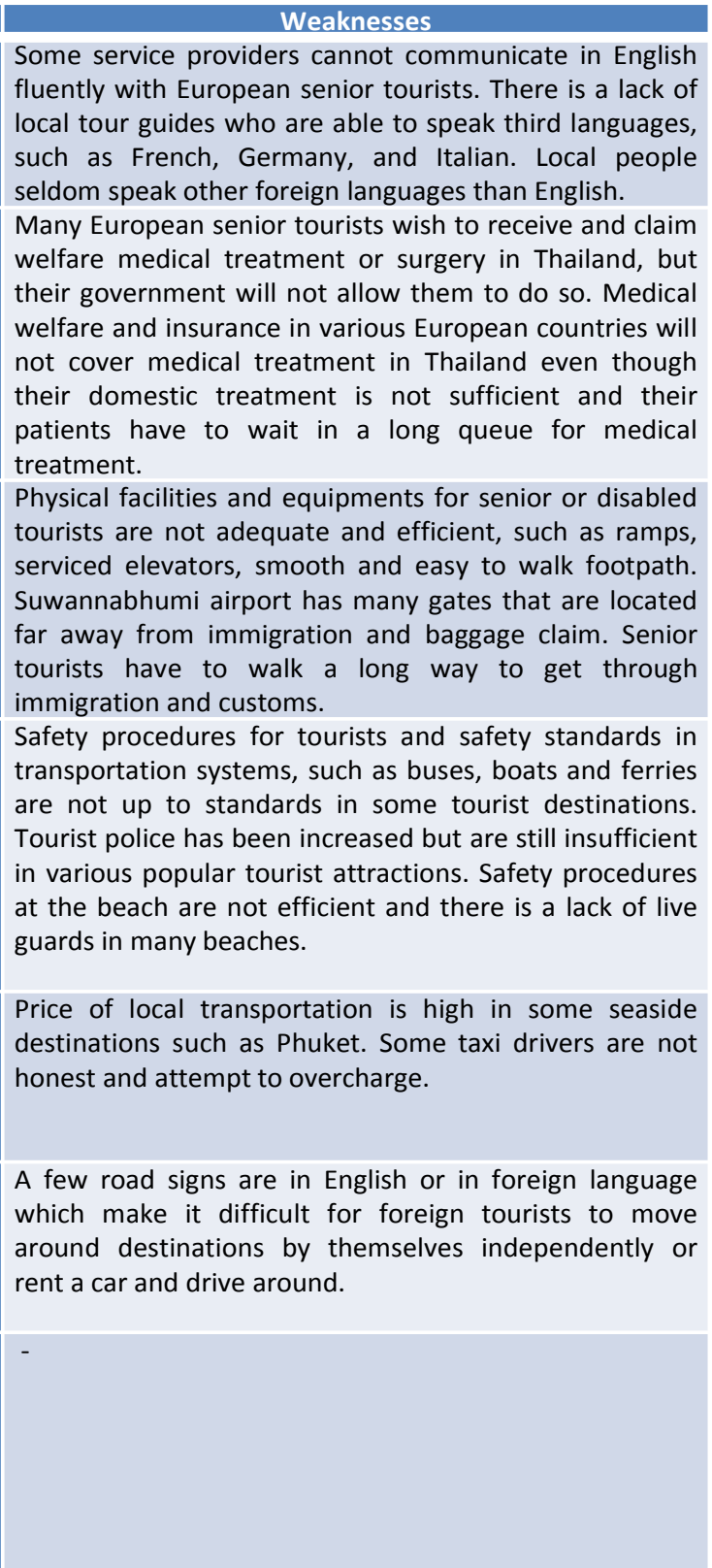

Some service providers cannot communicate in English fluently with European senior tourists. There is a lack of local tour guides who are able to speak third languages, such as French, Germany, and Italian. Local people seldom speak other foreign languages than English.

any European senior tourists wish to receive and claim welfare medical treatment or surgery in Thailand, but ir government will not allow them to do so. Medical far away from immigration and baggage claim. Senior urists have to walk a long way to get through Tourist police has been increased but are still insufficient in various popular tourist attractions. Safety procedures at the beach are not efficient and there is a lack of live guards in many beaches.

Price of local transportation is high in some seaside destinations such as Phuket. Some taxi drivers are not honest and attempt to overcharge.

A few road signs are in English or in foreign language which make it difficult for foreign tourists to move around destinations by themselves independently or rent a car and drive around.

Table 6. Strengths and weaknesses of tourism resources, facilities and services for European senior tourists

\section{Limitations}

This study has limitations in association with data used because data were collected on the site where the respondents were already in Thailand. The result may not truly reflect their actual motivations and perceived importance of tourism components prior to visiting Thailand because some factors as perceptions, attitudes and travel experiences may influence the assessment while they were on site locations after the vacation experiences. Another limitation is that all the points shown in IPA grids were on a diagonal and this might indicate that the respondents classified on the same way importance and satisfaction. In addition, IPA also treats a sample as homogenous group, which may diminish the accuracy of the results when tourists differ in terms of the important rating they allocate to service attributes. 


\section{References}

Anderson, B. and Langmeyer, L. 1982 "The under-50 and over-50 traveler: A profile of similarities and differences."Journal of Travel Research, 20(4): 20-24.

Backman K., Backman, S., Silverberg, K.

1999 "An investigation into the psychographics of senior nature-based travellers." Tourism Recreation Research, 14(1): 13-22.

Bai, B.X., Jang, S., Cai, L.A., and O’Leary, J.T.

2001 "Determinants of travel mode choice of senior travelers to the United States." Journal of Hospitality \& Leisure Marketing, 8(3/4): 147-168.

Baloglu, S. and Shoemaker, S.

2001 "Prediction of senior travelers' motorcoach use from demographic, psychological, and psychographic characteristic." Journal of Travel Research, 40(1): 12-19.

Cleaver, M., Muller, T., Ruys, H., Wei, S.

1999 "Tourism product development for the senior market, based on travel-motive research." Tourism Recreation Research, 24(1): 5-11.

Crompton, J.L.

1979 "Motivations for pleasure vacation." Annals of Tourism Research, 6(4): 408-424.

Dann, G.M.S.

2001 "Senior tourism." Annals of Tourism Research, 28(1): 238-240.

Farnum, J. and Hall, T.

2007 "Exploring the utility of importance performance analysis using confidence interval and market segmentation strategies." Journal of Park \& Recreation Administration, 25(2): 64-83.

Fleischer, A., and Pizam, A.

2002 "Tourism constraints among Israeli Seniors." Annals of Tourism Research, 29(1): 106-123.

Fridgen, J.D.

1996 Dimensions of Tourism, MI: ButterworthHeinemann.

Hall, C. M.

2006 "Demography." In Dimitrios Buhalis and Carlos Costa, (eds.) Tourism Management Dynamics: Trends, Management and Tools. Burlington: Elsevier Butterworth-Heinemann, 9-18.

Horneman, L., Carter, R., Wei, S., Ruys, A. 2002 "Profiling the senior traveler: an Australian perspective." Journal of Travel Research, 41(1): 2338.

Hsu, C.H.C.

2001 "Importance and dimensionality of senior motorcoach traveler choice attributes." Journal of Hospitality and Leisure Marketing, 8(3/4): 51-70.

Hsu, C.H.C. and Huang, S.

2008 "Travel motivation: a critical review of the concept's development." In A.G. Woodside and D. Martin (eds), Tourism Management: Analysis,
Behavior, and Strategy, Cambridge: CAB International.

Huang, L. and Tsai, H.-T.

2003 "The study of senior traveler behavior in Taiwan." Tourism Management, 24: 561-574.

Immigration Bureau

2008 Statistical Report of International Visitors. Royal Thai Police.

Jang, S.C. and Wu, C.-M.E.

2006 "Senior travel motivation and the influential factors: an examination of Taiwanese seniors." Tourism Management, 27: 306-316.

Jang, S., Ha, A. and Silkes, C.A.

2009 "Perceived attributes of Asian foods: from the perspective of the American customers." International Journal of Hospitality Management, 28(1): 63-70.

Javalgi, R.G., Thomas, E.G. and Rao, S.R.

1992 "Consumer behavior in the U.S. pleasure travel marketplace: an analysis of senior and nonsenior travelers." Journal of Travel Research, 31(2): 14-20.

Koh, S., Jung-Eun, J. and Boger Jr, C.A.

2009 "Importance-performance analysis with benefit segmentation of spa goers." International Journal of Contemporary Hospitality Management, 22(5): 718-735.

Koss, L.

1994 "Hotel developing special packages to attract senior travelers." Hotel and Motel Management, 209(3): 37.

Lindqvist, L.-J.and Bjork, P.

2000 "Perceived safety as an important quality dimension among senior tourists." Tourism Economics, 6(2): 151-158.

Littrell, M.A.

2004 "Senior travellers: tourism activities and shopping behaviours." Journal of Vacation Marketing, 10(4): 348-362.

Martilla, J.A. and James, J.C.

1977 "Importance-performance analysis." Journal of Marketing, 41(1), 77-9.

Ministry of Tourism and Sports

2008 Thailand Tourism Statistics. Available athttp://www.mots.go.th.

Moutinho, L.

2000 Strategic Management in Tourism. New York: CABI Publishing.

Norman, W., Daniels, M., McGuire, F. and Norman, C.

2001 "Whiter the mature market: an empirical examination of the travel motivations of neo-mature and veteran-mature markets." Journal of Hospitality \& Leisure Marketing, 8(3/4): 113-130.

Patterson, I.

2002 "Baby boomers and adventure tourism: the importance of marketing the leisure experience." 
World Leisure, 2: 4-10.

Patton, J.

1990 Qualitative Evaluation and Research Methods. London: Sage.

Pearce, P. 1982 The Social Psychology of Tourist Behavior, Pergamon, Oxford.

Romsa, G. and Blenman, N.

1989 "Vacation patterns of the elderly German."Annals of Tourism Research, 16: 178188.

Sangpikul, A.

2008 "Travel motivation of Japanese Senior Travellers to Thailand." International Journal of Tourism Research, 10(1): 81-92.

Sellick, M.C. and Muller, T.E.

2004 "Tourism for the young-old and old-old." In Singh, T.V. (ed.)New Horizons in Tourism: Strange Experiences and Stranger Practices. Cambridge: CABI Publishing, 163-180.

Shoemaker, S.

1989 "Segmentation of the senior pleasure travel market." Journal of Travel Research, 27(3): 1422.

Shoemaker, S.

2000 "Segmentation the market: 10 years later." Journal of Travel Research, 39(1): 11-26.

Tourism Authority of Thailand

2006 Market and Demand for Senior Tourists. Available http://www2.tat.or.th/

longstay/thai/group.html.

United Nations Population Division

1998 World Population Projections to 2150. New York: United Nations.

World Economic Forum

2009 The Travel \& Tourism Competiveness Report 2009.

World Tourism Organization

2005 Draft White Paper: a Look into Tourism's Future with the World Tourism Organization, 21 October 2005.

You, X. and O'Leary, J.T.

1999 "Destination behaviour of older UK travellers." Tourism Recreation Research, 24(1): 23-24.

Zhang, H.Q. and Chow, I.

2004 "Application of importance-performance model in tour guides' performance: Evidence from main" land Chinese outbound visitors in Hong Kong." Tourism Management, 25(1): 81-91.

Zimmer, Z., Brayley, R., Searle, E. and Mark, S.

1995 "Whether to go and where to go: identification of important influences on senior and decisions to travel." Journal of Travel Research, 33(3): 3-10.
Recibido:

$15 / 02 / 2011$

Reenviado:

$30 / 09 / 2011$

Aceptado:

$31 / 10 / 2011$

Sometido a evaluación por pares anónimos 